\title{
Synthesis of branched and linear 1,4-linked galactan oligosaccharides
}

\author{
Andersen, Mathias C. Franch; Boos, Irene; Kinnaert, Christine; Awan, Shahid Iqbal; Pedersen, Henriette \\ L.; Kracun, Stjepan K; Lanz, Gyrithe; Rydahl, Maja G; Kjærulff, Louise; Håkansson, Maria \\ Total number of authors: \\ 15
}

Published in:

Organic and Biomolecular Chemistry

Link to article, DOI:

10.1039/C7OB03035E

Publication date:

2018

Document Version

Peer reviewed version

Link back to DTU Orbit

Citation (APA):

Andersen, M. C. F., Boos, I., Kinnaert, C., Awan, S. I., Pedersen, H. L., Kracun, S. K., Lanz, G., Rydahl, M. G., Kjærulff, L., Håkansson, M., Kimbung, R., Logan, D., Gotfredsen, C. H., Willats, W. G. T., \& Clausen, M. H. H.' (2018). Synthesis of branched and linear 1,4-linked galactan oligosaccharides. Organic and Biomolecular Chemistry, 16(7), 1157-1162. https://doi.org/10.1039/C7OB03035E

\section{General rights}

Copyright and moral rights for the publications made accessible in the public portal are retained by the authors and/or other copyright owners and it is a condition of accessing publications that users recognise and abide by the legal requirements associated with these rights.

- Users may download and print one copy of any publication from the public portal for the purpose of private study or research.

- You may not further distribute the material or use it for any profit-making activity or commercial gain

- You may freely distribute the URL identifying the publication in the public portal 


\section{Accepted Manuscript}

This article can be cited before page numbers have been issued, to do this please use: M. C. F. Andersen, I. Boos, C. Kinnaert, S. Awan, H. Pedersen, S. K. Kracun, G. Lanz, M. G. Rydahl, L. Kjærulff, M. Håkansson, R. Kimbung, D. Logan, C. Gotfredsen, W. G. T. Willats and M. H. H. Clausen, Org. Biomol. Chem., 2018, DOI: $10.1039 / C 7 O B 03035 E$.

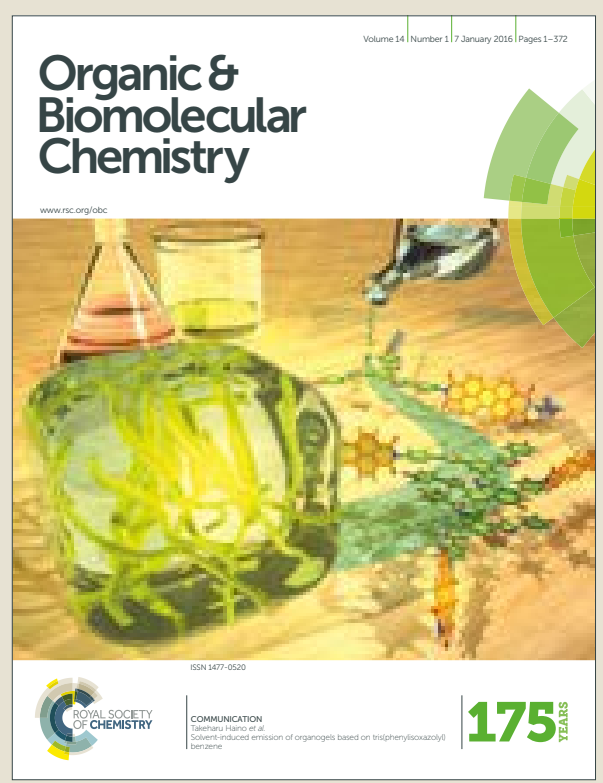

This is an Accepted Manuscript, which has been through the Royal Society of Chemistry peer review process and has been accepted for publication.

Accepted Manuscripts are published online shortly after acceptance, before technical editing, formatting and proof reading. Using this free service, authors can make their results available to the community, in citable form, before we publish the edited article. We will replace this Accepted Manuscript with the edited and formatted Advance Article as soon as it is available.

You can find more information about Accepted Manuscripts in the author guidelines.

Please note that technical editing may introduce minor changes to the text and/or graphics, which may alter content. The journal's standard Terms \& Conditions and the ethical guidelines, outlined in our author and reviewer resource centre, still apply. In no event shall the Royal Society of Chemistry be held responsible for any errors or omissions in this Accepted Manuscript or any consequences arising from the use of any information it contains. 


\title{
Synthesis of branched and linear 1,4-linked galactan oligosaccharides
}

Mathias C. F. Andersen, ${ }^{a}$ Irene Boos, ${ }^{a}$ Christine Kinnaert, ${ }^{a}$ Shahid I. Awan, ${ }^{a}$ Henriette L. Pedersen, Stjepan K. Kracun, ${ }^{\mathrm{b}}$ Gyrithe Lanz, ${ }^{\mathrm{a}}$ Maja G. Rydahl, ${ }^{\mathrm{b}}$ Louise Kjærulff, ${ }^{\mathrm{a}}$ Maria Håkansson, ${ }^{\mathrm{c}}$ Raymond Kimbung, ${ }^{\mathrm{c}}$ Derek T. Logan, ${ }^{\mathrm{c}}$ Charlotte H. Gotfredsen, ${ }^{\mathrm{a}}$ William G. T. Willats, ${ }^{\mathrm{d}}$ Mads H. Clausen ${ }^{\mathrm{a}}$ *

a Center for Nanomedicine and Theranostics, Department of Chemistry, Technical University of Denmark, Kemitorvet 207, DK-2800, Kgs. Lyngby, Denmark

${ }^{b}$ Department of Plant and Environmental Sciences, University of Copenhagen. Thorvaldsensvej 40, 1871 Frederiksberg C, Denmark

${ }^{c}$ SARomics Biostructures AB, Medicon Village, S-223 81 Lund, Sweden

${ }^{d}$ School of Agriculture, Food \& Rural Development, Newcastle University, Newcastle upon Tyne, NE1 7RU, United Kingdom

*mhc@kemi.dtu.dk, tel: +4545252131

\begin{abstract}
We report the synthesis of linear and branched $(1 \rightarrow 4)$-D-galactans. Four tetra- and one pentasaccharide were accessed by adopting a procedure of regioselective ring opening of a 4,6-O-naphthylidene protecting group followed by glycosylation using phenyl thioglycoside donros. The binding of the linear pentasaccharide with galectin-3 is also investigated by determination of a co-crystal structure. The binding of the $(1 \rightarrow 4)$-linked galactan to Gal-3 highlights oligosaccharides of pectic galactan, which is abundant in the human diet, as putative Gal-3 ligands.
\end{abstract}

\section{Keywords}

Plant oligosaccharides, RG-I, $(1 \rightarrow 4)$-D-galactan, CRD, galectin-3. 


\section{Introduction}

Carbohydrates are highly complex structures synthesized and metabolized by nearly all organisms. In particular, plant cell wall polysaccharides exhibit a broad diversity in their saccharide composition. One major class of polysaccharides present in plants is pectins, which are divided into three main types, namely homogalacturonan (HG), rhamnogalacturonan (RG) I and II. RG-I is a heteropolymer with a backbone of alternating $\alpha$-linked L-rhamnose and D-galacturonic acid residues with the extensive branching of galactans, arabinogalactans, and arabinans. ${ }^{1,2}$ It has been shown that certain pectins have health promoting effects, in particular for the inhibition of metastasis and cancer cell growth. ${ }^{3,4}$ These health benefits are assumed to be linked to their interaction with galectins. ${ }^{5,6}$ Galectins are carbohydrate- binding proteins with a defined carbohydrate recognition domain (CRD) which has a high affinity for glycans containing $\beta$-D-galactose residues. The galectin family is classified by the organization of the CRDs into three distinct types: prototype, chimera and tandem repeat. The only galectin of the chimera type is galectin-3 (Gal-3). ${ }^{3,7}$ The unique $N$-terminal coiled-coil region of Gal-3 is responsible for oligomerization. ${ }^{8}$ Consequently, the binding of galactose can occur either in a monomeric or oligomeric form of the lectin. ${ }^{9}$ The binding affinity of Gal-3 increases if galactose is linked to other saccharides, in particular to $N$-acetyl-lactosamine-containing glycoconjugates. ${ }^{10,11} \mathrm{Gal}^{-3}$ is involved in several biological processes such as cell-cell interactions, cell development and proliferation as well as apoptosis. ${ }^{10,12}$ Therefore, changes in Gal-3 expression levels are linked to the development of cancer and have been shown to have a role in metastasis. ${ }^{13}$

Recently, Stegmayr et al. tested RG-1 polysaccharides as well as well-defined synthetic oligosaccharides as potential galectin-3 inhibitors using a fluorescence anisotropy assay. They generally found weak inhibition and their results suggest that the activity is not due to interaction with 
the galectin carbohydrate binding site. ${ }^{14}$ We have engaged in a research program with two main purposes: 1) to develop efficient synthetic methods to target well-defined oligosaccharides that are representative of microdomains from the heterogeneous and complex pectic polysaccharides; and 2) to probe interactions between these oligosaccharides and biologically important proteins, including monoclonal antibodies and lectins. In the current study, we wanted to synthesize both naturally occurring branched and linear beta-linked oligogalactans found in the RG-I backbone of pectin, as well as analogues with one or two alpha-linkages. We decided to target the linear $(\mathbf{1}, \mathbf{2})$ and branched $(\mathbf{3}-\mathbf{5})$ galactans shown in Figure 1, in order to obtain structures with a size that is synthetically feasible while retaining likelihood of protein binding. We furthermore desired to probe the interaction between the oligosaccharides and galectin-3, starting with the linear galactan $\mathbf{2}$.

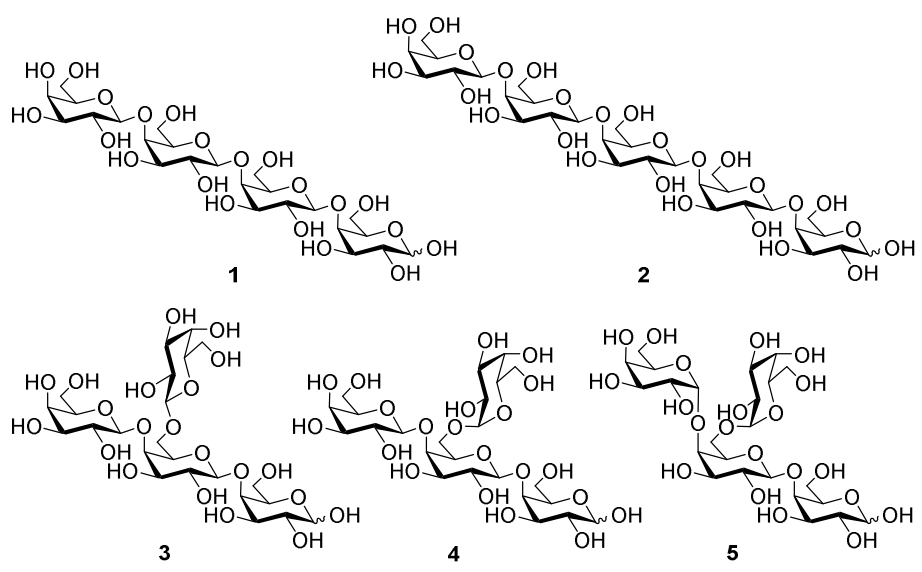

Figure 1: Target structures

\section{Results and Discussion}

To glycosylate the $\mathrm{C} 4-$ and $\mathrm{C} 6-\mathrm{OH}$ in a sequential manner, which was needed for the branched structures 3-5, it was necessary to find a protecting group strategy that allowed regioselective deprotection. The benzylidene acetal is often used for 4,6-protection since it can be regioselectively 
opened under reductive conditions. ${ }^{15-17}$ However, its use is limited by the fact that the resulting benzyl ether is a permanent protecting group in most strategies. Several other acetals have been developed that allow selective deprotection of the corresponding ether. The most common is the $p$-methoxybenzylidene acetal. ${ }^{18-20}$ Regioselective cleavage of the $p$-methoxybenzylidene acetal results in a $p$-methoxybenzyl (PMB) group, which can be cleaved using oxidative conditions without affecting benzyl- and acyl protecting groups. ${ }^{21,22}$ Unfortunately, the $p$-methoxybenzylidene acetal is much more acid labile than its unsubstituted counterpart. ${ }^{23,24}$ Instead it was decided to use the less common (2-naphthyl)methylene acetal as temporary protecting group. This acetal and its corresponding ether are less sensitive to acid, but due to the electron-rich ring system they still have many of PMB's advantages. ${ }^{19}$ The regioselective reductive opening of the acetal with $\mathrm{NaCNBH}_{3} / \mathrm{HCl}-\mathrm{OEt}_{2}$ results in the C6-O-NAP ether, which can be removed by oxidation with DDQ. ${ }^{25,26}$ This feature would make it possible to selectively deprotect first the 4-position and later on selectively cleave the C6-O-NAP. With this in mind, the two monosaccharide building blocks $6^{27}$ and $7^{28}$ were synthesized according to literature procedures (see Supporting Info).

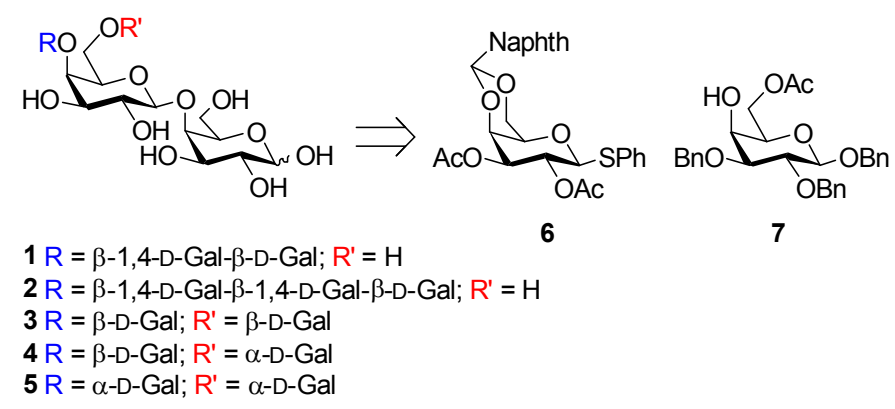

Scheme 1: Retrosynthetic analysis

NIS/TESOTf-promoted ${ }^{29}$ coupling of donor $\mathbf{6}$ and acceptor 7 in $1: 1 \mathrm{CH}_{2} \mathrm{Cl}_{2} / \mathrm{CH}_{3} \mathrm{CN}$ afforded $\beta$-glycoside 8 in $77 \%$ yield (Scheme 2). A regioselective reductive opening of the naphthylidene acetal 
was achieved by treatment with $\mathrm{NaCNBH}_{3} / \mathrm{HCl} \cdot \mathrm{OEt}_{2}{ }^{30}$ to give the disaccharide acceptor 9 in $83 \%$ yield.

Donor 6 was coupled to 9 under the same conditions, to give the $\beta$-linked trisaccharide 11 (Scheme 2) in $81 \%$ yield. A glycosylation between disaccharide 9 and known donor $\mathbf{1 0}^{31}$ led to the $\alpha, \beta$-linked trisaccharide 13 in a comparable yield. In the latter case, the use of a 1:1 $\mathrm{CH}_{2} \mathrm{Cl}_{2} / \mathrm{Et}_{2} \mathrm{O}$ solvent mixture resulted in improved $\alpha$-selectivity. ${ }^{32,33}$

The NAP group on both trisaccharides 11 and $\mathbf{1 3}$ was selectively removed by oxidative cleavage with DDQ in $\mathrm{CH}_{2} \mathrm{Cl}_{2} / \mathrm{MeOH} / \mathrm{H}_{2} \mathrm{O}(3: 1: 0.25) .{ }^{34,35}$ However, it was observed that addition of $20 \%$ methanol was crucial to avoid simultaneous deprotection of the benzyl groups. It is noteworthy that the naphthylidene acetal in $\mathbf{1 1}$ is stable under these conditions. ${ }^{19}$
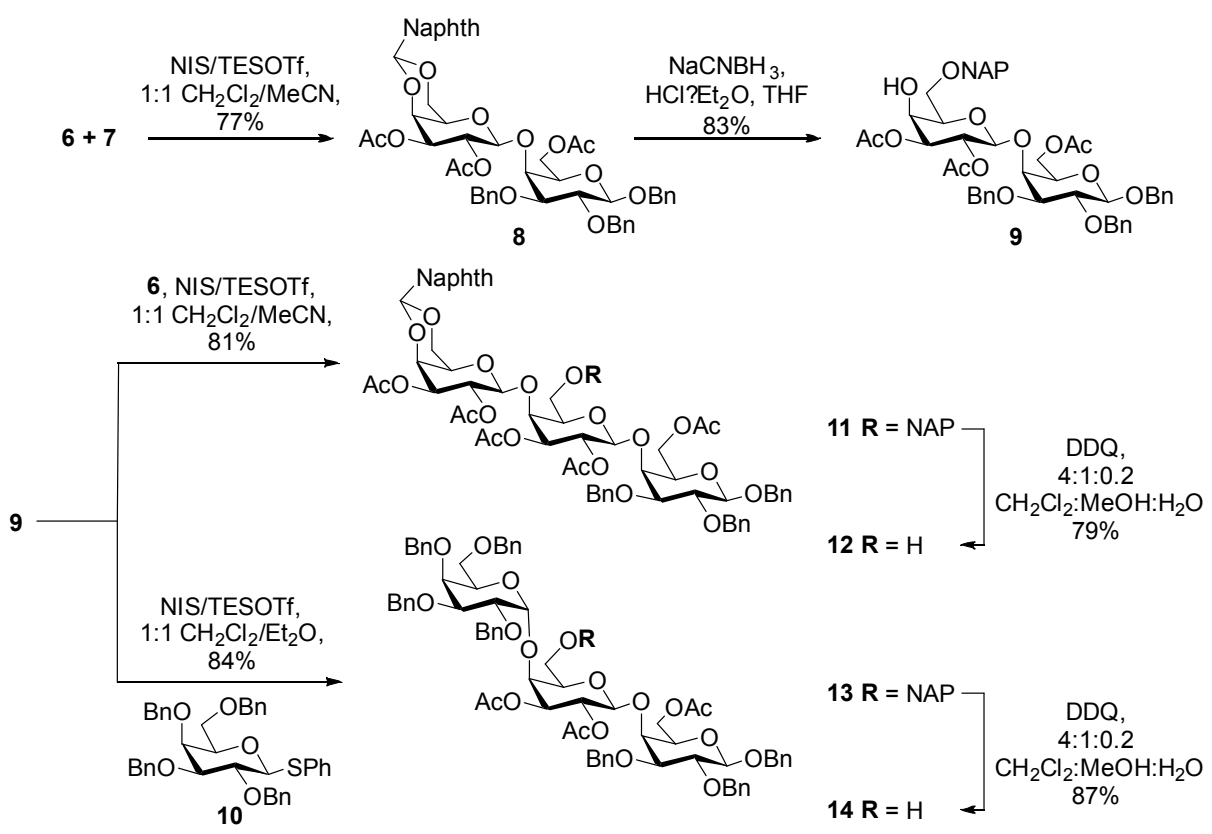

Scheme 2: Synthesis of trisaccharides $12 \& 14$

Coupling of the two trisaccharides $\mathbf{1 2}$ and $\mathbf{1 4}$ to either donor $\mathbf{6}$ or donor $\mathbf{1 0}$ using standard conditions afforded the three tetrasaccharides 15, 16 and 17 in good yields (75-81\%, Scheme 3). Trisaccharide 11 
was further regioselectively deprotected using $\mathrm{NaCNBH}_{3} / \mathrm{HCl} \cdot \mathrm{OEt}_{2}$ and subsequently coupled with 6 to give the linear tetrasaccharide 18 (Scheme 3). Repeating the deprotection and coupling cycle led to pentasaccharide 19.

Transesterification with $\mathrm{NaOMe} / \mathrm{MeOH}$ followed by hydrogenolysis over $\mathrm{Pd} / \mathrm{C}$ gave the four unprotected tetrasaccharides 1, 3-5 and pentasaccharide 2. A high amount of palladium (20 mol\%) and addition of acetic acid was necessary to obtain full conversion due to catalyst poisoning by 2-methylnaphthalene. ${ }^{25}$

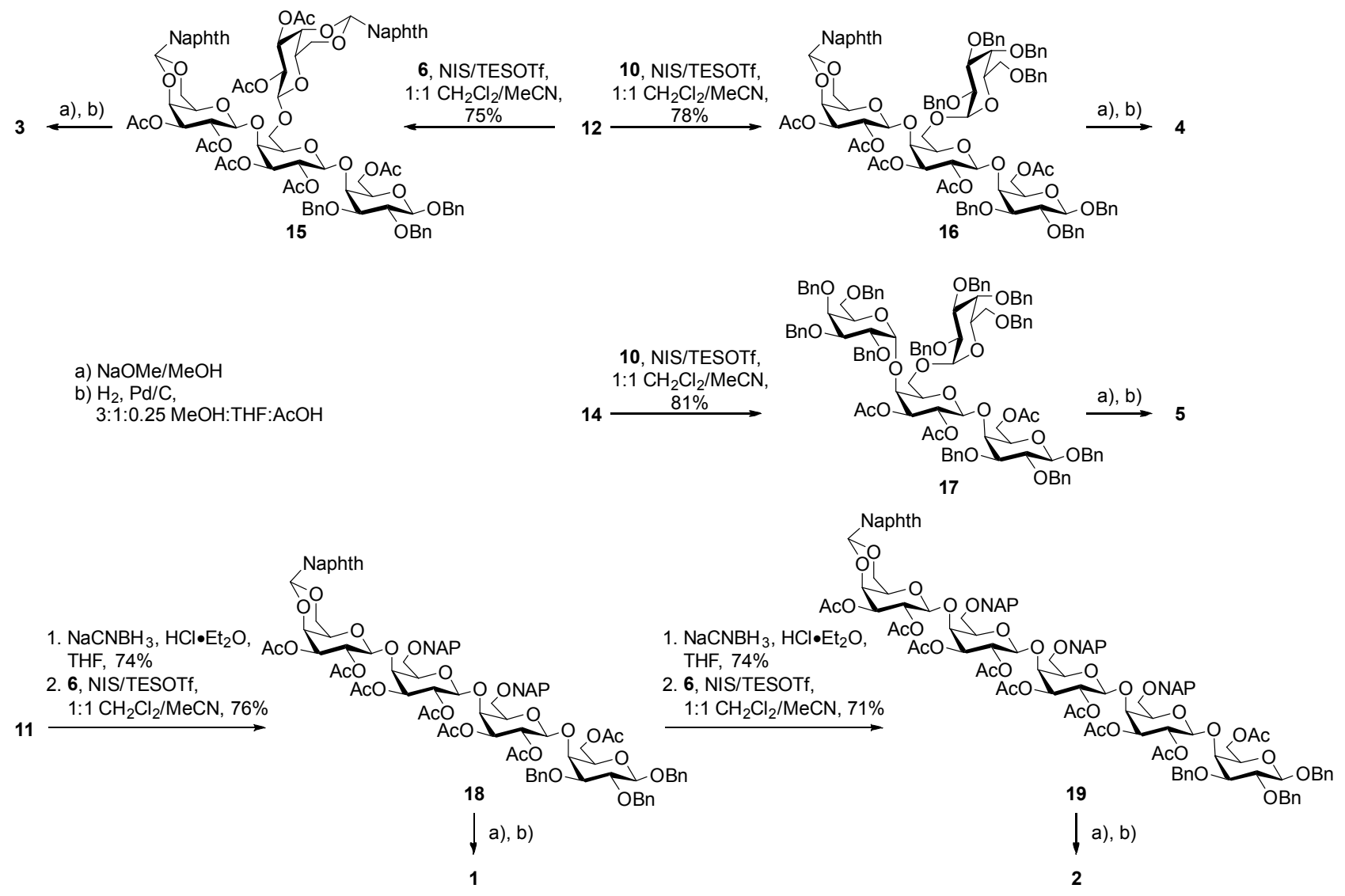

Scheme 3: Synthesis of target oligogalactans 1-5 
The unprotected oligosaccharides were conjugated to BSA and immobilized on microarrays together with other plant oligosaccharides in order to characterize protein-carbohydrate interactions. The results of the antibody screening are summarized in the work of Pedersen et al. ${ }^{36}$ The linear saccharide 2 was further used to characterize the galactosyltransferase activity of galactan synthase 1 (GALS1). ${ }^{37}$

To investigate the CRD of Gal-3, we decided to investigate co-crystallization with synthetic oligosaccharides. It has been hypothesized that the carbohydrate recognition domain of Gal-3 can accommodate a linear tetrasaccharide. ${ }^{38}$ If this is the case, oligosaccharides of four or more residues are likely to have higher binding affinity than $\mathrm{N}$-acetyl-lactosamine (LacNAc), which has previously been used as a scaffold for the development of Gal-3 inhibitors. Consequently, it was decided to start by cocrystallizing Gal-3 in complex with the linear pentasaccharide 2.

The co-crystallization presented some challenges. Lactose contaminants in the first protein sample occupied the binding site and thereby precluded co-crystallization with the ligand, already indicating weak binding of the pentasaccharide. However, use of a lactose-free batch of protein and a higher ligand concentration made it possible to obtain a crystal structure of Gal-3 in complex with pentasaccharide 2 at $1.4 \AA$ resolution. The structure is shown in Figure 2. Contrary to our expectations, Gal-3 only binds to two of the five galactose residues. The remaining residues are too flexible to be observed. Moreover, the second galactose residue has much weaker electron density than the first one (Figure 2B). Since the first residue has full occupancy and there is presumably no hydrolysis of the ligand, this means that the second residue is significantly more flexible. Given that the binding site has evolved to bind glucose at the second site, it is perhaps not surprising that galactose binds with lower affinity. The C4-epimerization that relates galactose to glucose results in a configuration in which, no matter what the torsion angle around the glycosidic bond, the second galactose moiety is unable to 
achieve the interactions made by glucose. Instead, the second galactose adopts a conformation in which the 6-hydroxymethyl functional group is projected towards the protein instead of the C3-hydroxyl group in glucose. Significant interactions observed between the C3-OH of glucose and Arg162/Glu184 are lost, and a water molecule binds there instead (Figure 2C). $\mathrm{O} 1$ of the second galactose is projected away from the binding surface, making it difficult for further $\beta$-(1 $\rightarrow 4)$-coupled galactose units to make contact with the protein. The structure demonstrates that the central sugar binding site (sites C and D in the accepted nomenclature of Leffler et $\left.a l .^{38}\right)$ cannot tightly bind $\beta-(1 \rightarrow 4)$-coupled galactose units. This is consistent with predictions made by Stegmayr et al. on the basis of molecular modelling ${ }^{14}$. Structures are available of larger glycans in complex with the Gal-3 CRD, e.g. the tetrasaccharides lacto- $N$-tetraose (LNT) and lacto- $N$-neotetraose (LNnT) that form the core of some glycosphingolipids present on mammalian cells and the acetamido ganglioside $\alpha-2,3$-sialyllactose. ${ }^{39}$ However, all of these contain a lactose $(\mathrm{Gal}-\beta(1 \rightarrow 4)-\mathrm{Glc})$ disaccharide in sites $\mathrm{C}$ and $\mathrm{D}$, and additional interactions are made with the protein in site B through linkage to the 3-OH of Gal. Accommodation of other sugars in site D is demonstrated by the complexes of Gal-3 CRD with various derivatives of the Thomsen-Freidenreich antigen $($ Gal- $\beta(1 \rightarrow 3)$-GalNAc- $\alpha(1 \rightarrow \mathrm{O})-$ Ser/Thr $){ }^{40}$ The $\beta-(1 \rightarrow 3)$-linkage orients the GalNAc moiety in site D such that O4 interacts with Glu184 instead of O3 in lactose; further stabilizing interactions are made by water-mediated hydrogen bonds to the $N$-acetyl group. Furthermore, the success of thiodigalactosides as very high affinity inhibitors of Gal-3 $3^{41,42}$ demonstrates that digalactosides can bind to sites $\mathrm{C}$ and $\mathrm{D}$; however in this case the galactose units are $\beta-(1 \rightarrow 1)-$ linked, allowing a reorientation of the second galactose such that $\mathrm{O} 2$ is able to mimic the interactions of $3-\mathrm{OH}$ in glucose perfectly. 
Nevertheless, even though the binding of the $\beta$ - $(1 \rightarrow 4)$-linked galactan to galectin-3 seems to be poor based on the crystal structure, consistent with earlier work on $\beta-(1 \rightarrow 4)$-linked Gal disaccharides using fluorescence anisotropy ${ }^{14}$, this does not exclude it as a potential ligand of Gal-3. Since Gal-3 is a chimeric galectin, binding to several digalactan motifs could result in a significantly higher total binding avidity. ${ }^{43}$ However, since only two galactose residues of 2 were shown to bind to Gal-3, we decided not to pursue co-crystallization with the remaining four oligosaccharides $(\mathbf{1}, \mathbf{3}-\mathbf{5})$ since such studies were highly unlikely to lead to further insights.

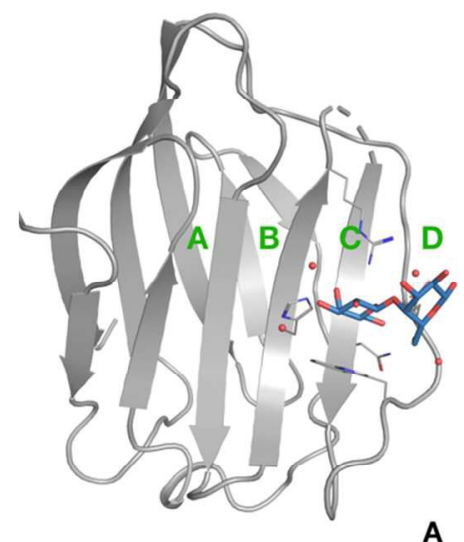

A

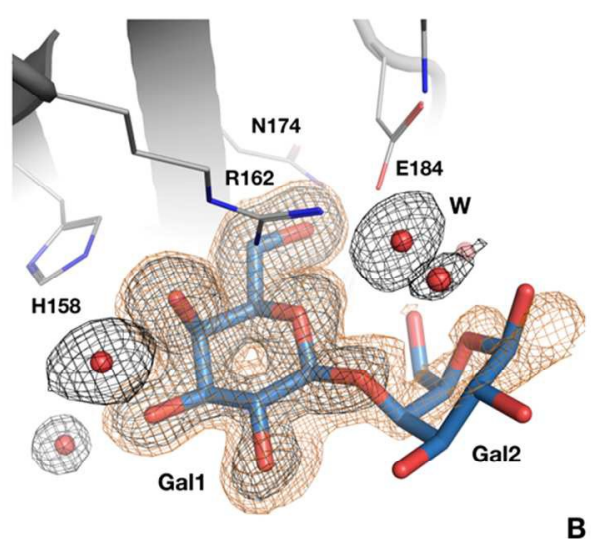

B

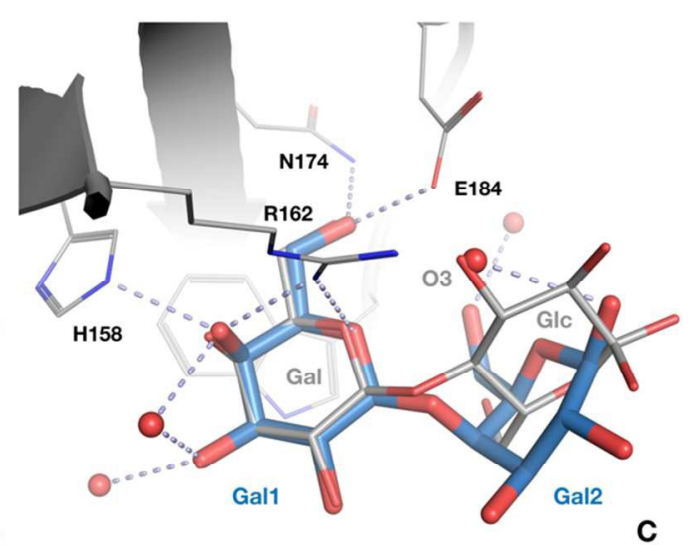

Figure 2: A) Overall view of the binding of the pentasaccharide to the Gal-3 CRD. B) Electron density for the first two galactose moieties of the pentasaccharide co-crystallized with the Gal-3 CRD. To illustrate the weakness of the density for the second galactose, the electron density map is contoured at two different levels around the saccharide: $1.0 \sigma$ (black) and $0.5 \sigma$ (orange). For the water molecules the map is contoured at $1.0 \sigma$. Important residues in the binding site are labelled. The water molecule that binds in the position of the glucose $3-\mathrm{OH}$ in lactose is labelled W. C) Hydrogen-bonding interactions of the first two Gal moieties with Gal-3 are shown as dotted grey lines. For comparison, 
the lactose complex (PDB ID 3ZSJ, Saraboji et al., Biochemistry 2012) is shown as thin grey sticks. It can clearly be seen that the well-ordered water molecule replaces $\mathrm{O} 3$ of glucose.

\section{Conclusion}

An efficient synthetic route to smaller linear and branched oligogalactans have been developed. The 4,6-naphthylidene group proved useful, as it could be reductively opened to provide 6-O-NAP protected acceptors or removed entirely to give diol acceptors. Glycosyl donors with either benzyl or acetyl protection at the 2-position provided $\alpha$ - and $\beta$-selective glycosylation reactions, respectively. Finally, the linear pentasaccharide 2 was co-crystallized with Gal-3, resulting in an X-ray crystal structure at $1.4 \AA$ resolution. The structure confirmed that galactans are ligands for Gal-3 - but also that the linear, beta-1,4 galactans bind poorly, as only two of the five galactose residues were resolved in the structure. The work described here should pave the way for future studies of both pectic galactans and their analogues as well as of ligands for Gal-3.

\section{Acknowledgments}

We acknowledge financial support from the Danish Council for Independent Research "A biologydriven approach for understanding enzymatic degradation of complex polysaccharide systems" (Grant Case no.: 107279), the Carlsberg Foundation, the Danish Strategic Research Council (GlycAct and SET4Future projects), the Villum Foundation (PLANET project) and the Novo Nordisk Foundation (Biotechnology-based Synthesis and Production Research). We thank staff at the 1911-3 beamline of the MAX-II synchrotron for help with data collection.

\section{References}


(1) Burton, R. A.; Gidley, M. J.; Fincher, G. B. Nat. Chem. Biol. 2010, 6 (10), 724.

(2) Caffall, K. H.; Mohnen, D. Carbohydr. Res. 2009, 344 (14), 1879.

(3) Nangia-Makker, P.; Honjo, Y.; Sarvis, R.; Akahani, S.; Hogan, V.; Pienta, K. J.; Raz, A. Am. J. Pathol. 2000, 156 (3), 899.

(4) Zhang, T.; Zheng, Y.; Zhao, D.; Yan, J.; Sun, C.; Zhou, Y.; Tai, G. Int. J. Biol. Macromol. 2016, $91,994$.

(5) Gao, X.; Zhi, Y.; Sun, L.; Peng, X.; Zhang, T.; Xue, H.; Tai, G.; Zhou, Y. J. Biol. Chem. 2013, $288(47), 33953$.

(6) Glinsky, V. V.; Raz, A. Carbohydr. Res. 2009, 344 (14), 1788.

(7) Nangia-Makker, P.; Conklin, J.; Hogan, V.; Raz, A. Trends Mol. Med. 2002, 8 (4), 187.

(8) Rogers, J. a; Read, R. D.; Li, J.; Peters, K. L.; Smithgall, T. E. Biochemistry 1996, 271 (29), 17519.

(9) Lepur, A.; Salomonsson, E.; Nilsson, U. J.; Leffler, H. J. Biol. Chem. 2012, 287 (26), 21751.

(10) Dumic, J.; Dabelic, S.; Flögel, M. Biochim. Biophys. Acta - Gen. Subj. 2006, 1760 (4), 616.

(11) Argüeso, P.; Panjwani, N. Exp. Eye Res. 2011, 92 (1), 2.

(12) Nangia-Makker, P.; Nakahara, S.; Hogan, V.; Raz, A. J. Bioenerg. Biomembr. 2007, 39 (1), 79.

(13) Hasan, S. S.; Ashraf, G. M.; Banu, N. Cancer Lett. 2007, 253 (1), 25.

(14) Stegmayr, J.; Lepur, A.; Kahl-Knutson, B.; Aguilar-Moncayo, M.; Klyosov, A. A.; Field, R. A.; Oredsson, S.; Nilsson, U. J.; Leffler, H. J. Biol. Chem. 2016, 291 (25), 13318. 
(15) Xu, J.; Vasella, A. Helv. Chim. Acta 1999, 82 (10), 1728.

(16) Ohara, K.; Lin, C.-C.; Yang, P.-J.; Hung, W.-T.; Yang, W.-B.; Cheng, T.-J. R.; Fang, J.-M.; Wong, C.-H. J. Org. Chem. 2013, 78 (13), 6390.

(17) van Steijn, A. M. P.; van der Ven, J. G. M.; van Seeventer, P.; Kamerling, J. P.; Vliegenthart, J. F. G. Carbohydr. Res. 1992, 229 (1), 155.

(18) Evans, D. A.; Kim, A. S.; Metternich, R.; Novack, V. J. J. Am. Chem. Soc. 1998, 120 (24), 5921.

(19) Lipták, A.; Borbás, A.; Jánossy, L.; Szilágyi, L. Tetrahedron Lett. 2000, 41 (25), 4949.

(20) Kaburagi, Y.; Osajima, H.; Shimada, K.; Tokuyama, H.; Fukuyama, T. Tetrahedron Lett. 2004, 45 (19), 3817.

(21) Horita, K.; Yoshioka, T.; Tanaka, T.; Oikawa, Y.; Yonemitsu, O. Tetrahedron 1986, 42, 3021.

(22) Georg, G. I.; Mashava, P. M.; Akgün, E.; Milstead, M. W. Tetrahedron Lett. 1991, 32 (27), 3151.

(23) Yan, L.; Kahne, D. Synlett 1995, 1995, 523.

(24) Misra, A. K.; Mukherjee, I.; Mukhopadhyay, B.; Roy, N. Indian J. Chem. - Sect. B Org. Med. Chem. 1999, $38 B(1), 90$.

(25) Matthew J. Gaunt; Jinquan Yu, A.; Spencer, J. B. J. Org. Chem. 1998, 63 (13), 4172.

(26) Xia, J.; Abbas, S. a; Locke, R. D.; Piskorz, C. F.; Alderfer, J. L.; Matta, K. L. Tetrahedron Lett. 2000, 41, 169.

(27) Lázár, L.; Mező, E.; Herczeg, M.; Lipták, A.; Antus, S.; Borbás, A. Tetrahedron 2012, 68 (36), 
7386.

(28) Clausen, M. H.; Jørgensen, M. R.; Thorsen, J.; Madsen, R. J. Chem. Soc. Perkin Trans. 12001 , 543.

(29) Clausen, M. H.; Madsen, R. Chem. - A Eur. J. 2003, 9 (16), 3821.

(30) J. Garegg, P.; Hultberg, H.; Wallin, S. Carbohydr. Res. 1982, 108 (1), 97.

(31) Xie, J.; Molina, A.; Czernecki, S. J. Carbohydr. Chem. 1999, 18 (5), 481.

(32) Satoh, H.; Hansen, H. S.; Manabe, S.; van Gunsteren, W. F.; Hu?nenberger, P. H. J. Chem. Theory Comput. 2010, 6 (6), 1783.

(33) Wulff, G.; Rühle, G. Angew. Chemie Int. Ed. English 1974, 13 (3), 157.

(34) Herczeg, M.; Mező, E.; Lázár, L.; Fekete, A.; Kövér, K. E.; Antus, S.; Borbás, A. Tetrahedron 2013, 69 (15), 3149 .

(35) Liao, W.; Locke, R. D.; Matta, K. L.; Wong, C.-H.; Alderfer, J. L.; Matta, K. L.; Varki, A.; Matta, K. L. Chem. Commun. 2000, $119(5), 369$.

(36) Pedersen, H. L.; Fangel, J. U.; McCleary, B.; Ruzanski, C.; Rydahl, M. G.; Ralet, M.-C.; Farkas, V.; von Schantz, L.; Marcus, S. E.; Andersen, M. C. F.; Field, R.; Ohlin, M.; Knox, J. P.; Clausen, M. H.; Willats, W. G. T. J. Biol. Chem. 2012, 287 (47), 39429.

(37) Liwanag, A. J. M.; Ebert, B.; Verhertbruggen, Y.; Rennie, E. A.; Rautengarten, C.; Oikawa, A.; Andersen, M. C. F.; Clausen, M. H.; Scheller, H. V. Plant Cell 2012, 24 (12), 5024.

(38) Leffler, H.; Carlsson, S.; Hedlund, M.; Qian, Y.; Poirier, F. Glycoconj. J. 2002, 19 (7-9), 433. 
(39) Collins, P. M.; Bum-Erdene, K.; Yu, X.; Blanchard, H. J. Mol. Biol. 2014, 426 (7), 1439.

(40) Bian, C. F.; Zhang, Y.; Sun, H.; Li, D. F.; Wang, D. C. PLoS One 2011, 6 (9).

(41) Delaine, T.; Collins, P.; MacKinnon, A.; Sharma, G.; Stegmayr, J.; Rajput, V. K.; Mandal, S.; Cumpstey, I.; Larumbe, A.; Salameh, B. A.; Kahl-Knutsson, B.; van Hattum, H.; van Scherpenzeel, M.; Pieters, R. J.; Sethi, T.; Schambye, H.; Oredsson, S.; Leffler, H.; Blanchard, H.; Nilsson, U. J. ChemBioChem 2016, 17 (18), 1759.

(42) Hsieh, T.-J.; Lin, H.-Y.; Tu, Z.; Lin, T.-C.; Wu, S.-C.; Tseng, Y.-Y.; Liu, F.-T.; Hsu, S.-T. D.; Lin, C.-H. Sci. Rep. 2016, 6 (1), 29457.

(43) Cooper, D. N. W.; Barondes, S. H. Glycobiology 1999, 9 (10), 979. 